\title{
19. Yüzyıl Osmanlı Tarihinin Ana Kaynakları: Buyruldu ve İlmühaber Defterlerinin Tahlili
}

\author{
Main Sources of 19. Century Ottoman History: Analysis of \\ The Buyruldu and Certificate Register Books
}

\section{Mehmet GÜNEŞ*}

\begin{abstract}
$\ddot{O} z$
Osmanlı'da devlet işlerini görüşmek üzere toplanan Divan-ı Hümayun, ilk zamanlarda her gün tertip edilirdi, zamanla haftada dört gün ve daha sonra iki gün, en sonunda üç ayda bir toplanmaya başladı. Bu toplantıların azalmasıyla birlikte devlet işleri, daha ziyade sadrazamın düzenlediği divanlarda görüşülmeye başlandı. Divan-ı Hümâyun'da bulunan bürolar da Babıâli'ye taşındı. Babıâli'de devlet işlerini vezir-i azam ya da sadrazam yürütmekteydi. Sadrazamın idaresi altındaki bürolar içerisinde önemli bir yere sahip olan Mektubi kalemi, taşradan sadrazama gelen yazıları teslim alınıp düzenler, sadrazamın taşra idarecileri ile merkez memurlarına göndereceği yazıları yazardı. Bu yazıların birer kopyası da defterlere kaydedilerek muhafaza edilirdi. 19. Yüzyllda resmi dairelerde çeşitli vesilelerle yazllan ve büyük bölümü günümüzde Başbakanlık Osmanlı Arşivi’nde mevcut olan bu kayıtlar, Osmanlı tarihi araştırıcıları için çok önemli temel malzemelerdir. Bu arşivde bulunan Buyruldu ve İlmühaber Defterleri de içerdiği hükümlerin önemine ve tarih araştırıcılarına sağlayacă̆ katkllara binaen irdelenmesi gereken bir kaynak grubudur. Bu makalede ele alınan Buyruldu ve Ilmühaber Defterleri, Sadaret makamından çıkan emirleri ihtiva eden önemli bir fon durumundadır ve bunlar A.DVNS.BUY.ILMM.d olarak kısaltılmaktadır. Bu defterler, yoğun olarak Ístanbul ve taşradaki mahalli meseleleri ele almakla birlikte yabanci tüccar ile tebaaya ve gemilerin durumuna dair önemli bilgileri de içermektedir. Bu konuları izah eden bu makale, söz konusu defterleri açılamak suretiyle Osmanlı tarihini araştırıcılarına yol gösterme gayesini gütmektedir.
\end{abstract}

Anahtar Kelimeler: Sadaret, Divan-ı Hümayun, Babıâli, Buyruldu, İlmuhaber, Defter.

* Dr., Başbakanlık OsmanlıArşivi, İstanbul,mhmgunes@gmail.com 


\begin{abstract}
Imperial Court that assembled to interview state works in the Ottoman had been organized every day first times, gradually began to assemble four days and later two day a week, eventually once in three month. Together with decreasing of these assemblies state works began to be interviewed more in the courts that sadrazam organized. Bureaus in Imperial Court were moved to Sublime Porte. Grand vizier or sadrazam managed state works in Sublime Porte. Letter writer/chief secretary office which had an important place among offices under sadrazam, received and arranged registers coming from provinces to sadrazam and wrote writings that sadrazam would send to province administrators and central officials. One copy of these writings were preserved being registered to books. Registers written with various reasons by official bureaus in 19. Century and today many exist in Ottoman Archive of Prime Ministry are very important basic materials for the Ottoman history researchers. Buyruldu and Certificate Register Books in that archive are a group of source to be examined based on importance of judgments they contain and contributions they provide for history researchers and these are abbreviated as A.DVNS.BUY.ILM.d. Although these books deal with local matters in Istanbul and provinces, they also include important knowledge about conditions of foreign merchants and subjects and ships. This article explaining these topics intends to show a way for the Ottoman history researchers by explaining mentioned books.
\end{abstract}

Keywords: Sadaret, Imperial Court, Sublime Porte, Buyruldu, Certificate, Register book.

\title{
Giriş
}

Osmanl1 Devleti, merkezde Sadaret ile nezaretler, meclisler ve sair resmi birimlerin birbirleri arasında ve yine bu birimlerin taşradaki mahalli idareciler ile şahıslarla yürüttükleri yazışmaları titizlikle muhafaza etmiştir. Yüzy1llar boyunca korunan bu kayıtlar, günümüze kadar gelmiş ve artık tarih araştırmacılarının kullanacakları materyaller olmuşlardır. Bu resmi kayıtlar, günümüzde Türkiye Cumhuriyeti'nin Başbakanlık, bakanlık, silahlı kuvvetler ve diğer idari birimleri bünyesinde bulunan muhtelif arşivlerde muhafaza edilmektedirler.

Osmanlı dönemine ait vesikalarının yoğun olarak bulunduğu ve tarihçilerin önemli ölçüde istifade ettikleri bir kurum, Başbakanlık bünyesinde faaliyetlerini sürdüren Osmanlı Arşivi'dir. Bu arşivde mevcut milyonlarca evrak, tarihin farklı alanlarında araştırma yapan kişilere veri sağlaması açısından önemli bir yere sahiptir. Osmanlı'nın hüküm sürdüğü dönemi, devletin tuttuğu kayıtlarla ortaya koyan ve devletin farklı kademelerine ait yazışmaları içeren belge ve defterler, Osmanlı Arşivi'nde onlarca farklı fon adı altında bulunmaktadırlar. 
Siyasi, idari, mali ve sosyal açıdan ele alınabilecek bu kaynakların bazılarının analitik envanteri yapılmış ve evrakın içeriği hakkında özet bilgiler verilmiştir. Belge fonlarının incelenmesinde araştırmacılara önemli kolaylıklar sağlayan bu özet usulü, defter fonlarının incelenmesi hususunda ise aynı derecede bir kolaylığı sağlayamamaktadır; çünkü bazen onlarca hatta yüzlerce sayfayı bile bulabilen defterler hakkında yapılan birkaç satırlık özetler içerik hakkında çok da aydınlatıcı olmamaktadır. Bunun dışında bir de analitik envanteri yapılmayan ve sadece numara ve yıl bilgisi verilen defter ve belge fonları bulunmaktadır. Bu fonlarda ne tür bilgilerin bulunduğunun tespiti ise tamamen araştırmacıların tüm belgeleri ve defter sayfaların taramalarına kalmaktadır.

Osmanlı Arşivi’nde bulunan defter fonları, yeri geldiğinde yüksek lisans ve doktora öğrencileri tarafından transkripsiyonu ve değerlendirmesi yapılarak çalışılmakta ve bu şekilde tarih araştırıcılarının hizmetine sunulmaktadır. Ancak bu defterlerin tahliline dayanan tez dışı çalışmalar ise ihmal edilmektedir. Araştırıcıların çalışmalarına yardımcı olmak ve arşiv fonları hakkında temel bilgiler vermek de önemli bir hizmet olacaktır.

Burada ele alınan defterler de içerdikleri konuların çeşitliliği ve devletin en üst idari kademesinden yazılmış olması sebebiyle tarih araştırmacılarına önemli ve sağlam veriler sunmaktadır. Makalede, defterlerin içeriği orijinal sıralarına riayet edilerek açıklanmakta, böylece araştırıcılara defterlerdeki konu sırasını takip etme imkânı sağlanmaktadır. İçeriği maddeler halinde vermek anlamayı kolaylaştıran bir etken olsa da orijinal sırayı bozmamak adına konular sınıflamaya tabi tutulmadı.

\section{Babıâli ve Sadrazam}

Osmanlı Devleti'nin ilk dönemlerinden itibaren devlet işlerini görüşmek ve kararlar almak üzere haftanın belirli günlerinde devlet merkezinde Divan1 Hümâyun adı altında toplanan bir divan mevcuttu. Bu divan, ilk zamanlarda her gün ve Fatih'in ilk devirlerine kadar hükümdarın başkanlığında toplanırdı. Ancak bu toplantılar, 16. Yüzyıldan itibaren haftada dört güne ve daha sonra ikiye, en sonunda kapıkulu askerlerine ulufe vermek ve sefir kabul etmek üzere üç ayda bire indi. 18. Yüzyılın son yarısından itibaren toplantıların üç aya inmesi nedeniyle devlet işleri, sadrazamın ikindi divanına ve olağanüstü durumlarda toplanan şûraya intikal etti. Divan-1 Hümâyun'da bulunan kalemler ile defterler ve kayıtlar da bu süreçte Babıâli'ye geçti. ${ }^{1}$

${ }^{1}$ İsmail Hakkı Uzunçarşıl1, Osmanlı Devletinin Merkez ve Bahriye Teşkilatı, Türk Tarih Kurumu Basımevi, Ankara 1988, s. 1-7, 262. Divan-1 Hümâyun'un gelişimi, kurumlaşması 
Babıâli'de devlet işlerini padişahın adına idare eden ve padişahın mührünü taşıyan vezir-i azam ya da sadrazam görev yapmaktayd.. ${ }^{2} \mathrm{Bu}$ kişiler için 16. Yüzyıl sonlarına kadar çoğunlukla vezir-i azam tabiri kullanılırken sadr-1 âli ve sadr-1 azam gibi unvanlar da kullanılmaya başlandi; ancak sadrazam unvan1, 16. Yüzyılın ikinci yarısından itibaren yaygın hale geldi. Saray dâhilinde Kubbealtı denilen yerde hizmet eden sadrazamın görev yaptığı daireye önceleri Paşakapısı, Sadaret dairesi ve son olarak da Babıâli denildi. Sadrazamların en çok meşgul oldukları konuların başında tayin işlemleri gelirdi. Tüm tayin, azil, terfi ve terakkiler Enderun dışında, sadrazamın buyruldusuyla olurdu. Tımar tevcihleri ve tımarlarla ilgili davalar bakmak, bunun haricinde dava dinlemek ve hükme bağlamak, yeri geldiğinde yabancı devlet yetkilileriyle müzakere yapmak da görevleri arasındaydı. Sadrazamlar, sefer zamanında serdar-1 ekrem olarak savaşa giderlerdi. Divan-1 Hümâyun toplantısından sonra belirli günlerde arza girip padişaha telhis sunarlard1.

Babıâli'de hizmet veren temel bürolar ile memuriyetler Sadaret kethüdası, reisülküttab ve çavuşbaşıydı, bunların idaresi altında daha birçok büro görev yapardı. Bunların yanı sıra Babıâli'de bazı alt kalemler de vardı; bunlar sadrazamın özel kalemi durumundaki Mektubi kalemi, kethüdanın sorumluluğu altındaki Kethüda Kitabeti kalemi ile reisülküttabın idaresi altındaki Amedi kalemiydi. Divan-1 Hümâyun'daki kalemler de reisülküttabın idaresi altında Babıâli'ye taşınmışlardı. Bu yapı içinde önemli bir yere sahip olan Sadaret kethüdası, dâhili işlerin yürütülmesinde mühim bir işlev görürdü. Taşra idarecilerinin merkezle ilişkilerini sağlar ve sefer organizasyonunu yürütürdü. Babıâli'de görev yapan önemli bir daire ise taşradan sadrazama gelen yazıların teslim alınıp düzenlenerek sadrazama takdim edilmesi ișini icra eden Mektubi kalemiydi. Bu kalemde, ayrıca devletin herhangi bir işi hakkında sadrazamın taşra idarecilerine ve merkezdeki memurlara yazdığı buyruldu ve emir niteliğindeki diğer yazılar da yazılır ve birer suretleri kalem defterlerine kaydedilirdi. ${ }^{4}$

II. Mahmud döneminde 1836 yılında Sadaret Kethüdalığı, Umur-1 Mülkiye Nezareti'ne (Dâhiliye Nezareti); Reisülküttablık, Umur-1 Hariciye Nezareti'ne; Çavubaşılık, Divan-1 Deavi Nezareti'ne ve 1837'de

ve gerilemesiyle ilgili olarak ayrıca bakınız: Ahmet Mumcu, Divan-ı Hümayun, Phoenix Yayınevi, Ankara 2007, s. 1-10.

2 Ali Akyıldız, Tanzimat Dönemi Osmanlı Merkez Teşkilâtında Reform (1836-1856), Eren Yayıncılık ve Kitapçılık, İstanbul 1993, s. 25.

3 Mehmet İpşirli, "Sadrazam", Türkiye Diyanet Vakfi İslam Ansiklopedisi, cilt 35, İstanbul 2008, s. 415, 417.

4 Muzaffer Doğan, “Divân-1 Hümâyûn'dan Babıâli'ye Geçiş”, Yeni Türkiye, cilt 31, Ankara Ocak-Şubat 2000, s. 477, 480 . 
Defterdarlık, Maliye Nezareti'ne dönüştürülerek Osmanlı merkez teşkilatında önemli değişiklikler yapılmaya başlandı. Bu süreçte yapılan bir düzenlemeyle Sadaret ismi de Başvekâlet haline dönüştürüldü. Ancak II. Mahmud'un ölümünü müteakiben Hüsrev Paşa, padişah mührünü Rauf Paşa'dan alarak kendisini sadrazam olarak ilan edince Başvekâlet kurumu kaldırılarak tekrar Sadaret tesis edilmiş oldu. Sadrazamın konumu da hükümet üyeleri arasında koordinasyonu sağlamak ve onlara nezaret etmekti. Nezaretlerin teşkilini takip eden dönemde Sadaret bünyesinde faaliyet gösteren Sadaret Mektubi Kalemi, Sadaret'in dâhili ve harici yazışmalarını yürüten önemli bir birim durumundayd $1 .{ }^{5}$

\section{Buyruldu ve İlmühaberlerin Anlamı ve Muhtevası}

Buyruldu ya da buyuruldu kelimesi, Türkçe buyurmak kelimesinden gelmektedir. Buy(u)ruldu, Osmanlı diplomatiğinde sadrazam, vezir, defterdar, kazasker, kaptan paşa, beylerbeyi gibi yüksek rütbeli görevlilerin kendilerinden aşağı mevkide bulunan kişilere gönderdikleri emirler için kullanılan bir terimdir. Buyruldular, beyaz üzerine yazılanlar ile arz, telhis ve sair evrak üzerine yazılanlar olmak üzere iki türdür. Bunun yanı sıra merkeze ve taşraya yazılanlar olarak da ayrıma tâbi tutulabilirler. ${ }^{6}$

Fatih Kanunnamesi'ne göre padişahın tuğrasını taşıyan hükümler sadrazam, defterdar ve kazaskerlerin buyruldularıyla yazılabilirdi. Babıâli'nin Mektubi Kalemi'nden yazılanlara buyruldu-yı sâmi veya buyruldu-yı âli denilirdi. Buyruldularda elkabın (lakaplar) ilk kelimesinin üzerine doğruluğunu göstermek amaciyla "sah" işareti konulurdu. ${ }^{7}$

İlmühaber ise bir kararı bildirmek veya bir konu hakkında bilgi vermek üzere bir daireden diğer daire ya da dairelere yazılan belgedir. Bu belgelerde genellikle bir irade, buyruldu veya arzuhalden bahsedilerek konuya girilirdi. Sadrazamın buyruldusu ve padişahın iradesiyle kesinleşen kanun ve nizamlar, ilgili kalemlere ilmühaberler yoluyla bildirilirdi. ${ }^{8}$

$\mathrm{Bu}$ genel izahın ardından söz konusu defterleri açıklamaya geçmeden önce Osmanlı Arşivi'nde bulunan bu defter fonları hakkında da bazı bilgiler vermek faydalı olacaktır. Bu makalede ele alınan Buyruldu ve İlmühaber Defterleri, arşivde aynı fon dâhilinde belirtilen sekiz adet defteri ifade

5 A. Aky1ldı, Tanzimat Dönemi, s. 26, 28, 30

6 Mübahat S. Kütükoğlu, Osmanlı Belgelerinin Dili (Diplomatik), Kubbealtı Neşriyatı, İstanbul 1994, s. 197, 198

${ }^{7}$ M. S. Kütükoğlu, "Buyruldu", Türkiye Diyanet Vakfi İslam Ansiklopedisi, cilt 6, İstanbul 1992, s. $478,479$.

8 M. S. Kütükoğlu, "İlmühaber”, Türkiye Diyanet Vakfi İslam Ansiklopedisi, cilt 22, İstanbul, 2000, s. 151. 
etmektedir. Bu defterlerin ilk altısı arşiv tasniflerinde "Buyruldu" olarak son ikisi de "İlmühaber" olarak geçmekte ve dönem itibariyle 1811-1918/12261336 yılları arasını kapsamaktadır. Ancak buyruldu defteri olarak belirtilen 4 numaralı defterin ilk sayfasında defterin ilmühaber defteri olduğu; 7 numaralı defterin farklı başlıklarda ise bu defterin hem Buyuruld1-i Âli Defteri hem de Defter-i İlmühaber olduğu belirtilmektedir. Başbakanlık Osmanlı Arşivi kataloglarında 989 numaralı Divan-1 Hümâyun Defterleri Kataloğu'nda mevcut olan defterler, Sadaret Mektubi Kalemi Defterleri başlığı altında da açıklanmaktadır. Kısaltması A.DVNS.BUY.İLM.d olan bu fonun aç11ımı ise "Bab-1 Asafi Divan-1 Hümâyun Sicilleri Buyruldu ve İlmühaber Defterleri" şeklindedir. Her ne kadar rehberde, bu defter fonunun önünde "Bab-1 Asafi Divan-1 Hümâyun Sicilleri" ibaresi belirtilmemişse de A.DVNS.'nin açılımı esasen bu manaya gelmektedir. ${ }^{9}$

Başka fonlar içerisinde ve müteferrik kayıtlar arasında ilmühaber ve buyruldu kayitları ile defterlerinin bulunma ihtimali de olmakla birlikte burada ele alınan defterler, belirtilen fonun altında geçen sekiz defteri kapsamaktadır. Kısaltmanın başında kullanılan "A" harfi Tanzimat öncesi dönemin evrakı için Bab-1 Asafi'yi, Tanzimat ve sonrası dönemde ise Sadaret'i ifade etmektedir. Ne var ki burada ele alınan defter fonları hem Tanzimat öncesini hem de Tanzimat sonrasinı kapsamakta yani bu fonun başındaki "A" harfi, hem Bab-1 Asafi hem de Sadaret evrelerini içine almaktadır. ${ }^{10}$

3. A.DVNS.BUY.ILL.d Fonundaki Buyruldu ve İlmühaber Defterleri

\section{a. Buyruldu ve İlmühaber Defterleri 1}

İncelenen defter fonunun birinci olan buyruldu defteri, Haziran 1811/Cemaziyelevvel 1226 ile Ocak 1827/Cemaziyelâhir 1242 tarihleri arasını kapsamaktadır. Defterin kapak kısmında "Buyuruldı Defteri, Min Evâsit-1 Cumadelûla Sene 1226 İlâ Evâil-i Cumadelâhire Sene 1242” ifadesi bulunmaktadır. 18 x $30 \mathrm{~cm}$ ölçülerinde, son kısmında 106-119 arası sayfaları boş olan ve konuları yüz beşinci sayfada (elli üç varak)* biten defter,

9 Başbakanlık Osmanlı Arşivi Rehberi, Hazırlayanlar Yusuf İhsan Genç ve diğerleri, Başbakanlık Basımevi, Ankara 2010, s. 196, 197, 478. Not: Bu rehberde bu defter fonunun tarihleri 1811-1912 arası olarak verilse de bu fonun 8 numaralı defterinde son konunun tarihi 1918/1336'dır.

${ }^{10}$ Bab-1 Asafi ile Sadaret fonları, hem Osmanlı Arşiv Rehberi’nin kısaltmalar bölümünde hem de bilgisayar ortamındaki katalog adları kısmında "A" harfiyle gösterilmektedir.

* Bir varak iki sayfadan oluşan kitap yaprağı demektir (Şemseddin Sami, Kâmûs-ı Türki, cilt 1-2, Çağrı Yayınları, İstanbul 2001, s. 1489). 
Osmanlı diplomatiğinde yazı biçiminin değişime uğradığı bir süreci kapsaması itibariyle önemlidir; çünkü defter divani yazıdan 19. Yüzyılın yaygın diplomatik yazı türü olan rik'a yazısına geçişi de göstermektedir. Şöyle ki rik'a yazısı, Osmanlılar tarafından 18. Yüzyılın ikinci yarısından itibaren kullanılmaya başlayan ve 19. Yüzyılda yaygınlaşan ${ }^{11}$ basit bir yazı biçimidir. İşlek bir yazı olduğu için harfler birçok şekilde birleşme imkânına sahiptir. $^{12}$ Nitekim bu yazı türü 19 . Yüzyılda günlük hayatta, mektuplarda ve resmi yazılarda yaygın biçimde kullanılmış, Babıâli dairelerinde işlek hale gelmiştir. ${ }^{13} \mathrm{Bu}$ defterde de ilk bölümlerde görülen divani yazı, ilerleyen sayfalarda yer yer sadeleşerek tedricen yerini rik'a yazısına bırakmaktadır.

Fihristi bulunmayan bu defterde çeşitli vesilelerle kendilerine Sadaret'ten emir gönderilen kesimler arasında Kapudan-1 derya, Kapudan paşa, Kapudan paşa vekili, Tersane-i Âmire emini, Galata kadısı, Galata voyvodası, Reisülküttab, Çavuşbaşı, gümrük emini, liman nazırı, İstanbul kadısı, Havass-1 Refia kadıs1, Üsküdar kadısı, Haslar kadısı, Bahr-i Siyah Boğazı nazırı, zahire nazırı, Topcubaşı, Bostancıbaşı, Rum patriği, Ermeni patriği, Darphane-i Âmire nazırı, Yeniköy naibi, Haremeyn kalemi, Baruthane-i Âmire nazırı, Koru-yı Hümâyun zabıtı, kaza naibleri, kaza kadıları, Karahisar-1 Sahib sancağı mutasarrıfi, Hüdavendigar ve Kocaili sancakları mutasarrıfı, İstanbul gümrüğü emini, Bahr-i Siyah Boğazı'nın Anadolu tarafı muhafızı, Bahr-i Siyah Boğazı'nın Rumeli tarafı muhafızı, Bezzazistan kethüdası, Sipahiler ağası, defterdar bulunmaktadır.

Yukarıda belirtilen kişilere hitap eden yazılarda işlenen konular genel itibariyle Karadeniz'de yük taşırken hava muhalefetine maruz kalan Fransız iki ticaret gemisinin durumu; iş yeri açma izni, Avrupa tüccarının haklarının korunmas1, donanma için kereste temini, korsanlık faaliyetlerinin engellenmesi, davaların görülmesinde dikkat edilmesi gereken hususlar, gayrimüslimlerin hukukunun garanti altına alınması, gemilere ruhsat verilmesi, gemilerin yüklü veya yüksüz olarak Bahr-i siyah (Karadeniz) Boğazı'ndan geçerken izin kâğıtlarını memurlara ibraz etmelerine dikkat edilmesi, ateşli silahların kullanılmasını önlemeye yönelik emirler, Büyükdere ve Tarabya'da bulunan dükkânların durumu, İstanbul'un çeşitli yerlerindeki dükkânların kontrol edilmesi, yasak eşya taşımacıllı̆̆ının engellenmesi, yabancı devlet tüccarlarının getirdikleri mallardan tarifeye göre vergi vermeleri, usule aykırı davranışta bulunan gayrimüslimlerin

${ }^{11}$ M. S. Kütükoğlu, Osmanlı Belgelerinin, s. 67.

${ }^{12}$ M. Tayyib Gökbilgin, Osmanlı Imparatorluğu Medeniyet Tarihi Çerçevesinde Osmanlı Paleografya ve Diplomatik İlmi, Edebiyat Fakültesi Basımevi, İstanbul 1979, s. 46.

${ }^{13}$ Muhittin Serin, "Rik'a", Türkiye Diyanet Vakfi İslam Ansiklopedisi, cilt 35, İstanbul 2008 , s. 108 . 
engellenmesi, uygunsuz hareketlerinden dolayı huzursuzluğa sebep olan Hırvatların İstanbul'dan uzak tutulmaları, gayrimüslimlerin isyan halinde olan İbsilanti'ye meyil etmemeleri, iltizam usulüne dikkat edilmesi, Rum isyanı sebebiyle ehli İslam'ın olası tehlikelere karşı hazır ve tedarikli bulunmaları, deniz ve kara yoluyla kimsenin izin tezkeresi olmadan seyahat ettirilmemeleri, gemilerin sahte bandırayla seyahat etmelerinin önlenmesi, Dersaadet'ten çıkarılan İranlıların uygun yerlerde iskân edilmeleri, ehli İslam'ın kılık kıyafet konusunda israf etmemeleri ve belirli ölçülerin dışına çıkmamaları, ehli İslam'ın altın ve gümüşlerini ücreti karşılığında Darphane'ye vermeleri, ülkedeki yabancı uyruklu kişilerin arazi almalarına ve yerli gayrimüslim kızlarla evlenmelerine engel olunması, men-i mürur nizamının (seyahat izni) icrasına dikkat edilmesi, memurların görevlerine devam etmeleri ve bir özür olmadan görevi terk etmemeleri, gayrimüslimlerin lüzumundan fazla üzüm alarak içki üretmelerinin önlenmesi, memurların zamanında işlerinin başında bulunmaları, Dersaadet'teki İranlıların durumunun araştırılarak kayıt altına alınmaları, Sardinyalıların ticaret gemilerinin Karadeniz'de ticaret yapmalarına izin verilmesi; Frengistan'dan gelen Tevrat, Zebur ve İncil'lerin geri gönderilmesi ve gelenlerin de sahaflarda alınıp satılmaması; davası görülmek üzere taşradan Dersaadet'e gelenlerin durumları, İsveç gemilerinin Karadeniz'de dolaşmalarına izin verilmesi, kereste naklinin kontrol altına alınması, insanların cemaatle namaz k1lmalarının ve Cuma namazlarını gerektiği şekilde icra etmelerinin sağlanması, içki satılan yerlerden yıkılacak olanların yıkılması ve kalanlara ehli İslam'ın girmelerinin önlenmesi, İstanbul'da yangından zarar gören Müslümanların uygun yerlere yerleştirilmeleri, erzak, eşya ve başıboş kimselere nezaret etmek üzere muhtesib tayini, Samakocuk nezaretinin el değiştirmesi hakkındadır. Bunun dışında İngiltere elçisinin bir takririnin tercümesi ile İngiltere orta elçisinin takririnin tercümesi de muhtelif yerlerde verilmektedir.

\section{b. Buyruldu ve İlmühaber Defterleri 2}

Buyruldu ve İlmühaber Defterleri fonunun ikincisi olan bu defter, Ağustos 1826/Muharrem 1242 ile Mart-Nisan 1839/Muharrem 1255 tarihleri arasını kapsamaktadır. Defterin kapağında "Buyuruldı Defteri, ...Evâil-i Muharrem Sene 1242 İlâ Evâsıt-1 Muharrem Sene 1255" yazılıdır. Defterin içeriği Hicri 1242 yılı ve sonrasını kapsamaktaysa da ilk konusu, Hicri 1214 tarihli bir yazıyla başlamaktadır. 32 x $20 \mathrm{~cm}$ ölçülerinde, 1-3, 17-19 arası ile 166. sayfaları boş olan bu defterde ilk on dokuz sayfa sonradan numaralandırılmış, orijinal numaralandırma ise yirminci sayfadan itibaren ve birden başlatılmıştır. Dolayısıyla defterin son sayfa numarası sonradan yapılan numaralandırma itibariyle yüz altmış beş (yazılı kısım seksen varak) 
iken orijinalinde ise yüz kırk altıdır; bu sebeple referans verilirken her iki numaranın da göz önünde bulundurulması faydalı olacaktır. Bu defterde yazı tipi rik'adır.

Fihristi bulunmayan bu defterde kendilerine hitap edilen kesimler arasında Reisülküttab, Defterdar, İstanbul kadısı, Hassa mimarı, Rum patriği, Ermeni patriği, Bostancıbaşı ağa, Seretibba-yı hassa, Evkaf müfettişi, Darphane-i Âmire nazırı, İhtisab ağas1, Evkaf-1 Hümâyun nazırı, Hüdavendigar ve Kocaili ve Menteşe sancakları mutasarrıfı, Bahri Siyah Boğazı'nın Rumeli canibi muhafızı, Asakir-i Mansure-i Muhammediye Seraskeri, Anadolu valisi, Kapudan paşa, Baruthane-i Âmire nazırı, Havass-1 Refia kadısı, Galata kadısı ve nazırı, Üsküdar kadısı, Sadr-1 Rumeli, Sadr-1 Anadolu, gümrük emini, liman memurları, Serasker, Humbarahane-i Âmire nazırı, Humbaracıbaşı, Lağımcıbaşı, Zahire nazırı, Hahambaşı, Katolik patriği, rical-i Devlet-i Aliyye, Cebehanecibaşı, Boğaziçi muhafızı, Tophane-i Âmire nazırı, Ebniye-i Hassa müdürü, Ferik-i Hassa-i Şahane beylerbeyi, Boğaz nazırı, hacegan-1 divan-1 hümâyun mensubu, müşir-i hassa, Asakir-i hassa müşiri, İhtisab nazırı, Zahire nazırı, Takvim-i Vekâyihane-i Âmire nazırı vekili, kereste gümrüğü müdürü, şeyhler, Darphane-i Âmire defterdarı, Hariciye nazırı, Kapudan paşa kaymakamı, mühimmat-1 Harbiye nazırı, damad-1 şehriyari Halil Rıfat Paşa, Sisam beyi, Maliye nazırı, Üsküdar muhafızı, Bilâd-1 Selâse kadıları, Bab-1 Fetvapenahi, Su nazırı bulunmaktadır.

Söz konusu kişilere hitap eden yazılarda ele alınan konular, yirminci sayfaya kadarki bölümde genel itibariyle divan hukukuna ve umuruna ait mübaşirli evamir-i aliyyenin (emirler) teberdar ve hasekilere değil de sakabaşılar ile emsaline verilmesi ve iki pençe ile iki sah olmadıç̧a verilmemesi; taşrada zulüm yapanların cezalandırılması, kazalarda hâkimlerin defter ve imza harc1 adıyla aldıkları ücretler, kendilerini müstemen gibi göstererek cizyeden kurtulmaya çalışanların önlenmesi, fesat erbabının hanelerde iskân edilmemeleri, yabancı devlet tüccarının satın aldıkları müskirata ait vergiyi ödemeleri, davası olan kadınların bizzat meclis-i şer'de (mahkeme) hazır bulunmaları, eskiden beri Müslümanların meskûn oldukları menzillere keferenin iskân edilmemesi, tımar ve zeamet sahiplerinin haklarının korunması, muhtelif yerlerde güvenliğin temini ve halkın korunması, Bahr-i Siyah Boğazı'ndan geçişle ilgili kuralların icra edilmesi, iltizam ve malikâne usulüne riayet edilmesi, yabanc1 devlet konsoloslarından tezkere alarak muafiyet sağlamaya çalışan yerli reayanın engellenmesi, ülkeye giren veya ülkeden yabancı devletlere çıkarılan malların gümrüklerinin ahitnameye uygun olarak ödenmesi, kaza ve köylerini terk ederek başka yere giden vergi mükelleflerinin vergilerinin 
tahsili usulü, memur istihdamına dair takip edilecek usul, Rumeli'de ayan ve voyvodaların Arnavut sekban istihdam etmemeleri hakkındadır.

Defterde orijinal numaraların başladığı birinci, sonradan yapılan numaralandırmaya göre yirminci sayfada "İhtisab Nizamı ve Bazı Nizamata Dair Olan Buyuruldı ve Evamir-i Aliyye Defteridir" başlığı altında ülkede bozulan durumu düzeltmek için çalışıldığı belirtilerek ihtisap nizamı hakkında ayrıntılı bilgiler verilmektedir. Ancak tüm konular ihtisap hakkında değildir, ilerleyen sayfalarda ihtisap nizamının dışındaki konular da izah edilmektedir. Bu bölümde esnafin kontrol edilmesi, bekâr kişilerin mevcut hanlarda barınmaları, yeni hanlar yapılmaması, İstanbul'da başıboş kimselerin tutulmamas1, Dersaadet'e girmek üzere gelenlerin denetlenmesi, gayrimüslimlerin kıyafet kurallarına uymaları, yangında zarar gören esnafın zararını gidermek üzere çalışmalar yapılması, kereste nakli işinin kereste nazırı tarafından yürütülmesi, vilayetleri tarafına gidecek esnafa izin kâğıdı verilmesi hakkındaki nizam, meyve ve sebzeler için uygun fiyatlar belirlenmesi, Darphane-i Âmire'nin idare ettiği vakıfların Evkaf-1 Hümâyun nazırına havale edilmesi, men-i mürur nizamı gereğince seyahatin kontrol altına alınması, kadı ve hâkimlerin ahkâm-ı şer'iyyeye dikkat etmeleri, Müslüman ve gayrimüslim gemilerinin tahkik edilmesi, 1skat-1 cenin (çocuk düşürme) vakalarının önlenmesi, yabancı ticaret gemilerinin taşıdıkları mallardan tarifeye göre vergi alınması, gayrimüslim din adamlarının görev alanlarının tespiti, eşkinci zaim ve tımar erbabının Humbarahane-i Âmire'ye bağlanması, yabancı gemilerden alınıp ambarlarda tutulan malların satışa çıkarılması, taşradan İstanbul'a gelişlerin kontrol edilmesi ve uygunsuz hareketleri görülen kimselerin İstanbul'dan çıkarılmaları, düşmanlık yapan Rusya'ya karşı halkın uyarılması ve hazırlıklı olmalarının istenmesi, sürgün edilen kişilerin hanelerinin satışa çıkarılması, uygunsuz hareketleri görülen yabancıların Dersaadet'ten çıkarılmaları, Müslümanların içki içilen yerlere girmelerinin engellenmesi, sikkenin belirlenen fiyattan aşağıya alınıp verilmemesi, Galata'da francala firını açılması, kilise tamiri, Edirne ve Dersaadet arasındaki ulaşım için hayvan tedariki, verginin tespiti amacıyla sayım yapılması, yardıma muhtaç kişilere dağıtılmak üzere Kudüs patriğine akçe gönderilmesi, İstanbul'da hayvana binerek dolaşmanın kısıtlanması, gümrük tarifelerinin yenilenmesi, Rumeli ve Anadolu'da halkın kaydedilmesi, humbaracı ve lağımcılardan kalan tımarların durumu, Galata'da kilise inşası ve tamiri, yangınların yayılmasını önlemek amacıyla sokakların genişletilmesi, memurların işlerinin başında bulunmaları, cizye verisinin toplanmasına itina gösterilmesi, Katoliklerle Ermeniler arasında sorun çıkmasına izin verilmemesi, misafirlere çubuk ikram edilmesi âdetinin kaldırılması, tebaaya mahsus olan esnaflık ve ticarete Yunanistan'ın 
girmesinin önlenmesi ve bunların dükkân ve destgâhlarını tebaaya satmaları, Hristiyan mezheplerin birbirlerinin hukukuna riayet etmeleri, Rum milletinin istirahatinin sağlanması, uygunsuz hareketleri sebebiyle Dersaadet'ten çıkarıldıkları halde geri gelen Hırvatların kontrol altında tutulmaları, Takvim-i Vekâyi'nin içeriği hakkında düzenleme yapılması, kereste nakline izin verilmesi, Şeyh ve dervişlerin kılık kıyafetlerinin belirlenmesi ve bunlar dışında kimsenin kendilerini onlara benzetmemeleri, Asitane sokaklarının temiz tutulması, men-i mürur nizamının icra edilmesi, yangında zarar gören yerlerin keşfinin yapılması, gayrimüslimlerin fes alametleri, Müslümanların namaz için camilere gitmeye özen göstermeleri, arzuhallerin yazılmasına dair usul, medrese talebelerinin nüfus işleri ile seyahat durumları, bahriye için nefer tedarik edilmesi, Galata ve Beyoğlu civarında kiraya verilen dükkân ve mağazaları işletenlerin usulsüz hareketlerinin önlenmesi, asker emeklilerinin kayıt altına alınmaları, Asitane ve Bilâd-1 Selâse'de nüfus yoklaması yapılması, tımarlardan alınacak harçlar, ilmi gayelerle Paris'te bulunan kişilerin masraflarının karşılanması, taşrada ileri gelen kişilerin halk1 ezmelerine izin verilmemesi, 1skat-1 cenine dair ilaç verilmemesi, hastalık meydana gelirse karantina idaresine bildirilmesi; Dersaadet ve Bilâd-1 Selâse'de hane, sahilhane ve sair emlak satışlarının sıkı kontrol edilmesi; davalar hakkında gelen arzuhallerin göreceği muamele, yasak sikkelerin toplanmasi; Babıâli'ye tayin edilen odac1lar, kirpaspare toplama hakkının Fransa tebaasından birine verilmesi, İstanbul ihtisab nazırının vergi tahsili hususunda takdim ettiği takriri hakkındaki mütalaa açıklanmaktadır. Bunun dışında defterde Tekfurdağı'na sürülmüş olan Maraş eski valisi Celaleddin Paşa'nın durumu ele alınmakta ve Mısır valisi Mehmed Ali Paşa'nın hareketleri hakkında taşradaki memurlar ile ileri gelenlere bilgi verilmektedir.

\section{c. Buyruldu ve İlmühaber Defterleri 3}

Buyruldu ve İlmühaber Defterleri fonunun üçüncüsü olan buyruldu defterinin kapak kısmındaki yazı tahrip olmuştur. 34 x $23 \mathrm{~cm}$ ölçülerinde, başta bir boş, 182-184 sayfaları boş, 1-8 arası "m" (mükerrer) ve sonda bir numarası boş olan ve sonlara gelindikçe konuların tarih sıralamasında düzeni bozulmaya başlayan bu defter, Nisan 1839/Muharrem 1255 ile Ağustos 1861/Safer 1278 tarihleri arasını kapsamaktadır. Fihrist bölümündeki sekiz sayfadan sonra birden başlatın ve ilk sekiz sayfası "m" (mükerrer) olarak gösterilen, mükerrer sayfalardan sonra numarası dokuzdan devam ettirilen defterin son sayfa numarası yüz doksandır (yazılı kısım doksan sekiz varak). Defterde yazı tipi rik'adır.

Defterde kendilerine hitap edilen kesimler ve kurumlar; gümrük emini, liman memuru, Serasker, Maliye nazırı, İhtisab nazırı, Ebniye-i Hassa 
müdürü, İstanbul ve Bilâd-1 Selâse kadıları, Umur-1 Ticaret nazırı, Dâhiliye kâtibi, gümrükçü bey, Galata kadısı, Galata nazırı, liman nazırı, Hariciye nazırı, Hariciye nazırı vekili, Mukataat Hazinesi defterdarı, Rum, Ermeni ve Katolik patrikleri, Hahambaş1, Ticaret Nezareti, Liman Odas1, Rum milleti cemaat metropolitleri, Asakir-i Hassa müşiri, Kapudan paşa, Ermeni milleti muteberanı, Divan-1 Deavi Nezareti, Deavi Nezareti, Mektubi-i Sadr-1 âli Odas1, Meclis-i Muhasebe-i Maliye, Evkaf-1 Hümâyun Nezareti, Hariciye kitabeti, Bab-1 Seraskeri, kereste gümrüğü, iskele müdürü, Bahr-i Siyah Boğazı muhafızı, Darphane-i Âmire nazırı, Maliye hazinesi, Bab-1 Fetvapenahi, Tersane-i Âmire, Dâhiliye kâtibi, Hariciye kâtibi, Emtia gümrüğü, Haremeyn tercümanı, Hazine-i Hassa Nezareti, Tophane-i Âmire, Tersane-i Mamure, Ticarethane-i Âmire, Mektubi-i Hariciye, Tahvil kalemi, Ruus kalemi, Divan-1 Hümâyun tercüman1, Defterhane-i Âmire, Bab-1 Zabtiye, Meclis-i Vâlâ tahrirat kâtibi, Meclis-i Vâlâ Mazbata Odası, Meclis-i Vâlâ Evrak Odası, Babıâli Evrak Odası, Tuğrakeş efendi, Rum patrikhanesi, Ermeni patrikhanesi, Bab-1 Seraskeri Yoklama Odası'dır.

Başlangıç kısmında sayfa numarası, konu ve tarih bilgilerinin verildiği bir fihristi bulunan defterin içeriği genel itibariyle şöyledir:

Defterin fihristten sonraki ilk sayfasındaki başlıkta "Haza Defter-i Buyuruld1 ve İlmühaber Min Evâhir-i Muharremü'l-Harem Sene 1255" yazılıdır. Defterde ele alınan konular genel itibariyle Devlet-i Aliyye tüccarının gemilerinin gerektiğinde donanma maiyetine verilmesi, ticaret gemilerinin yabanc1 devlet tebaasına satılmaması, karantina hakkında nizam, Limni Ceziresi'nin tevziatı sırasında halka zulüm yapılmasının önlenmesi, Mekteb-i Maarif-i Adliye için alınan kitapların müdüre teslim edilmesi, Yunanlılara cizye kâğıdı verilmesi, zahire maddesinin değiş̧irilmesi, cülus-1 hümâyundan dolayı beratların yenilenmesi, payitahtta kârgir bina inşa edilmesi, Tersane-i Âmire'de amelenin yeterli dereceye çıkarılması, Avusturya ile Osmanlı arasındaki muvakkat ticaret anlaşması, zahire alış verişi, Katoliklerin patrikler tarafindan idare edilmesi, Süryani ve Yakubi Süryanilerin işleri için murahhasa tayini, Sardinya tüccarı ve tebaası hakkında anlaşma düzenlenmesi, Rum milletine ait mektebin tamiri, Galata ve Beyoğlu civarındaki dükkân ve sair yerlerin tahkiki ile uygunsuz hareketlere izin verilmemesi, küreğe konulan esnafın süresi dolunca aynı esnaflığa kabul edilmemeleri, Ramazan'da Babıâli'nin faaliyet göstermesi, İtalya ile yapılan ticaret anlaşmasının tarifesi, gayrimüslimler arasındaki meselelerin görüşülmesi, poliçeci esnafi hakkında konu, beratlı ve Hayriye tüccarının işlerinin Ticaret Nezareti tarafından görülmesi, Takvim-i Vekâyi'nin basım ve yayımı, Flemenk ve Belçika devletleriyle ticaret anlaşması yapılması, Meclis-i Umur-1 Nafia azası hakkında talimatname, 
Rumların Kudüs'teki ziyaretgâhları hakkında konu, Esliha nizamı, Rum patriği seçimi, Evamir-i aliyyenin Meclis-i Mahsus azası dışındakilere de yazılması, beratlı ve Hayriye tüccarının Meclis-i Ticaret'te görülecek davaları hakkında konu, Rum patriğinin vazifeleri, karantina memurlarıla tabiplerin harcırah ve maaşları, Toskana ve Danimarka ile yapılacak ticaret anlaşması, Karantina maddesine dair kaleme alınan nizamname, bir köyde Rum patriklerine mahsus sahilhanenin yeniden inşası, Prusya ile yapılacak ticari anlaşma, Yunan tebaasının Osmanlı'da esnaflık yapamaması, yüklü kayıkların seyahatleri hakkında konu, kereste ve odun nakliyle ormanların korunmas1, narhtan fazlaya erzak ve meyve satılmamas1, posta nizamnamesi, Ermeni patriği seçimi, mektupların posta tatarları tarafindan taşınması, mürur tezkeresi hakkında konu, posta memurlarının Maçin'de ikamet etmemeleri, memur ve kâtiplerin hizmetlerine devam etmeleri, Prusya ile yapılan anlaşmanın tarife defteri, Rum patriği seçimi ve tayini; kile ve kileciler hakkında nizam, İslam hanelerinin gayrimüslimlere satılmaması, bazı Ermenilerin tedibi, Dersaadet'e gelenlerin kayıt işlemlerine dikkat edilmesi, ticari işlerin görüşülmesi hakkında konu, beratlı Hayriye ve Avrupa tüccarı hakkında konu, davalara mübaşir tayini, tüm dairelerin Cuma günleri tatili, ormanlardan kereste ve odun kesimi, bazı katillerin serbest bırakılmaları, Hayriye ve Avrupa tüccarı arasındaki sorunların görüşülmesi, Ayazma İskelesi'ne ticaret gemilerinin yanaşmaları, Amerikalı bazı kaptanların Osmanlı iskelelerin(d)e vapur işletmeleri, bazı feriklerin mirimiran olmaları, posta nizamı ve mektupların hızla taşınması, Galata'da ehli İslam'ın tasarrufundaki evlerin satılmaması, mahkemeye kâtip tayini, karantina müdür ve vekilliğine muktedir memur istihdamı, beratlı Avrupa tüccarının basma imali, karaya vuran gemilerin mallarının kurtarılması, beldelerin imarı ve halkın refahı hakkında konu, Tophane-i Âmire işlerinin düzenlenmesi, Beyoğlu'nda yanan mahalle aralarında dükkân inşa edilmemesi, hukuki meselelerde taşradan gelen ilamlara memurlar tarafından yapılan işaretler, postaneye evrakın gönderilmesi durumu, Rusya ile ticaret anlaşması, yeni ticaret anlaşmasının Fransa memurlarıyla görüşülmesi, Ramazan'da Babıâli'nin gündüzleri açılması, Beyoğlu'ndaki dükkânların muteber olmayan kişilere kiraya verilmemesi, Latin reayasının Osmanlı'da iskânlarına izin verilmesi, Meclis-i Vâlâ Tahrirat Odası hulefasının durumları, taşra ahalisinin işlerinin görülmesi, memurların vaktinde işlerinin başında bulunmaları, resmi ve gayri resmi yazılara tarih konulması, zabıtan ve nizamiye neferlerinin amirleri huzurunda temenna yapmalar1, Maruniyet taifesinin Dersaadet'teki işlerinin görülmesi, taşrada yazı işlerinin hılı ve kolay yapılması, Osmanlı gemilerinin uğradıkları limanların isimleri, geceleri sokaklarda kandil yakılmas1, Bursa metropolitinin terekesi, Haramideresi adının değiştirilerek Saadet Deresi denilmesi, elkabın rütbe ve haysiyete göre yazılması, Sakız reayasının emlakinin kendilerine 
bırakılması, Yunan tüccarının liman ve iskelede eşya satabilmesi, umumi işlerin istenen sürede icra edilmesi, Protestanların hususi bir nezaret altında olmaları, Dersaadet ve Bilâd-1 Selâse'de inşa olunacak ebniye nizamnamesi, Ramazan'da tatil günleri dişında memurların göreve devam etmeleri, vapur ve yelkenlere binen bazı fukara ve seyyahlar için gümrük malından verilen meblağın sağlam bir usule bağlanması, memurların erken gelip geç gitmeleri, rütbe ve nişan hakkında nizamname ve buyruldu, sakalar kethüdasina berat verilmesi, ziraat ve sanayinin istenilen şekilde devamı, harap köprülerin tamiri, kâtiplerin bulundukların kalemin görevlerini ve ulum-1 âliyeyi tahsil etmeleri, bazı tüccarların Dersaadet'e hanelerini nakletmeleri vergi açısından müşkülatı doğurduğundan bunun devam etmemesi, memurların işlerine vaktiyle devam etmeleri, bir sarrafın bir zimmideki alacağının halledilmesi, bir şahsın zapt edilen mallarının iade ettirilmesi, yelkenlerle gönderilen fukara hakkında konu, zimmetinde miri mal olarak ölen memurların terekelerinden bu malın alınması, ilmiye ve kalemiyenin rütbe ve mansıpları için alınacak harçlar, sâdât-1 kiramın ispat-1 nesep etmeleri, Babıâli'de sofalarda sigara içilmemesi, taşrada cizye tahsili, beratlı Hayriye ve Avrupa tüccarından rüşvet ve sair suçla sanık olanların durumu, emval-1 eytamın muhafazası için hazırlanan tereke nizamnamesi, eytam sandıklarının idare ve muhafazası, hukuki meselelerin giderilmesi için Dersaadet'e gönderilen vekillerin sağlam kefile bağlanmaları, Şirket-i Hayriye Nizamnamesi, gemilerin Dersaadet'teki kereste dükkânlarına derya tarafindan yanaşmaları, yabancı devletlere duhan nakleden İngiltere ve Avusturya tüccarının ödeyeceği vergi, Mecidi nişanı hakkında nizamname, liyakatsiz kişilerin kalemlere kabul edilmemeleri, sikkelerin belirlenen fiyatla alınıp verilmesi, namaz k1lmayanların uyarılması ve kabul etmeyenlerin hapsedilmesi, bazı kişilerin tarlalarına bina inşa etmemeleri, taşraya memuren gönderilen kişilerin maaşlarının belirlenmesi, çocuksuz olarak ölenlerin miri arazileri, mal müdürlerinden kesilip kalem maaşına eklenen meblağın hazineye alınması, duhan rüsumunun Avusturya için olduğu gibi diğer devletler için de uygulanması, Rusya'nın belirttiği mezhep imtiyazının kabul edilememe durumu, kaleminden çıkmamak şartıyla memuriyete gidenler hakkında konu, Mersin İskelesi'ndeki yabancı tebaa sahilhanelerinin önündeki denize rıhtım inşası, Protestanlar hakkında valilere emir verilmesi, davalara mübaşir tayini hakkında nizamname ve sair yazı, Belgrad havalisindeki tımarlılardan alınan berat harçları, Deavi çavuşlarının nizam altına alınmaları, Meclis-i Cinayet'e dair nizamname, gemiyle taşınan fukara ve talebe hakkında konu; Sadaret ile Misır valisine mahsus elkab, hudud ve sınır derci hakkında konu; yabancı sefir, konsolos ve vekillerinin şahsi malzemelerinin gümrükten muaf tutulması, bir kazadaki çiftlik tartışmasının halledilmesi, tuğra çekme görevinin tuğrakeşlere ait olması, Prusya gemilerine verilecek izn-i sefine hakkında konu, bazı müşir ve 
feriklerin kalebend edilmeleri, senet ile mühim maddelerin damgalı kağıda yazılması, yabancı diyara gidecek gemilerin izn-i sefileri hakkında konu, kuzat ve nüvvabın hareketleri ve harçları, Selanik kalesi pişgahındaki arazinin satılmaması, bazı sancakların kazaları hakkında konu, telgrafhane için alınan şakirdan hakkında konu, cizyeden muaf olanların durumları, tasdikname ve harita gibi mühim evrakın bozulmaması için keseye konulması, bac resmi hakkında nizamname ve sair yazı, memurluğa ve sair hizmetlere tayin edilenlerin maaşları hakkında konu, bir şahsın arazisine müdahale edilmemesi, gümrük mültezimiyle tüccarı arasındaki ihtilafın giderilmesi, enfiye rüsumu hakkında konu, Fabrika-yı Hümâyun denilen hanın yanında yapılan han ile sokak hakkında konu, Kale-yi Sultaniye'deki yabancı konsolosların evlerinde ürettikleri şaraptan vergi alınmaması, memurların fabrika-yı hümâyun mamulatından aldıkları eşya paraları, Kıbrıs tımarlısının beratlarının yenilenmesi, hapis müddetinin ceza müddetine mahsup edilmesi, tercüme odası hulefası arttığı için çırak alınmaması, bazı karyelere eklenecek karyeler hakkında konu, inşa edilen bir cami ile medreseye vakfedilecek arazi, maliye işlerinin 1slahatı, Tırhala'daki bir karye ahalisinin hizmet yerlerine müdahale edilmemesi, müskirattan alınacak vergi, Latinlerin işlerinin Mezahib Odası'nda görülmesi, Süryani kilise ve manastırlarına müdahalenin önlenmesi, bir köy ahalisiyle bazı kişiler arasındaki arazi meselesi; Rumeli, Anadolu, Arabistan ve Cezayir-i Bahr-i Sefid'deki gümrükler hakkındadır.

\section{d. Buyruldu ve İlmühaber Defterleri 4}

Buyruldu ve İlmühaber Defterleri fonunun dördüncüsü olan defterin kapak kısmında "İlmühaber Defteri Min Evâil-i Rebiülevvel Sene 1261 İlâ Evâhir-i Rebiülâhir Sene 1284” yazılıdır. 21 x 30 cm ölçülerinde, 208-209 sayfaları boş olan bu defter, Mart 1845/Rebiülevvel 1261 ile Ağustos 1867/Rebiülâhir 1284 tarihleri arasını kapsamaktadır. Son iki sayfası boş olan ve konuları iki yüz yedinci sayfada biten bu defterin yazılı kısmı yüz yirmi varaktır. Defterin muhtelif yerlerinde "m" (mükerrer) sayfalar bulunmaktadır. Defterde yazı tipi rik'adır.

Öncekilerden farklı olarak bu defterde ve bundan sonra gelen diğer Buyruldu ve İlmühaber defterlerinde konular, istisnai durumlar dışında genel olarak herhangi bir makama hitap edilmeden açıklanmakta, altıncı defterde makamlar yine ifade edilmektedir. Bu nedenle de hitap edilen kesimler için (altıncı defter dışında) ayrı bir paragraf açılmaya gerek görülmedi.

Fihristi olmayan 4 numaralı defterin içeriği genel itibariyle şöyledir: Defterin ilk sayfasında "Ya Fettah, Haza Defter-i İlmühaberdir, Derzaman-1 Sadr-1 Suduru'l-Vüzera Hazreti Mehmed Emin Rauf Paşa Yesserallahu Mâ Yurid ve Mâ Yeşa ve Fi Eyyâmi Umur-1 Nezaret-i Hariciye Hazreti Mehmed 
Şekib Efendi Nâle Mâ Yetemennahu El-Vâki Fi Gurre-i Ra Sene 1261" yazılıdır. Defterde ele alınan ilk konu Selanik defterdarının azliyle yerine başkasının tayin edilmesi hakkındadır. Bundan sonra defterin büyük bölümünde bulunduğu üzere çeşitli yerlere yapılan müdür, kaymakam, mutasarrıf, muhassıl, vali, müşir, mal müdürü ve defterdar tayinleri yer almaktadır. Bunun dışında genel itibariyle Beyoğlu'nda meydana gelen yangından dolayı yol genişletme ve sair masrafların karşılanması, çeşitli muamelelere dair kâğıtlara mahsus damgalar düzenlenmesi, evlad-1 fatihanın idaresi hakkında konu, Selimiye Kışlası'nın eşyalarının sayımı ve tamiri, askerlerin tapuyla sahip oldukları boş arsaların durumu, erkân-1 ümera ve zabıtan-1 askeriyeden bir görev için bir yere gidenlerin masraflarını kendilerinin karşılamaları; Rumeli, Anadolu, Arabistan ve Cezayir-i Bahri Sefid'deki kalelerin masrafları; kalelerin nizam altına alınması, ordu-yı hümâyun ile Tophane-i Âmire'ye mensup taburların masraflarının karşılanması; sıla ve tebdili hava için vilayetlerine giden veya redif sınıfina nakledilerek vatanları tarafina giden neferlerin yol masraflarının karş1lanması; Karahisar-1 Sahib ve sair yerlerin ihtisab, kantar, bâc-1 kil ve bazar ile kereste vergileri hakkında konu; hazine-i hümâyun hademesinden ölen bir kişi uhdesindeki mandıranın başkasına tevcihi, Anadolu ve Rumeli'de münasip yerler seçilerek imar edilmeleri, askerlerin sıla ve tebdili hava için hazırladıkları arzuhallerin muamelesi, Haleb eyaleti dâhilindeki bir aşiretin iskânı hakkında konu, patrikhaneler mal-ı maktuunun tahsili, Cidde valisinin nüfuzunu artırmak amaciyla kendisine emr-i âli gönderilmesi, Dersaadet ve Bilâd-1 Selâse ile Boğaziçi'nde mahalle ve sokak aralarında yeni dükkân inşa edilmemesi, mühim maddelerin tahriri için bir kalem tesis edilmesi, âşar vergisi hakkında düzenleme yapılması, taşrada ihtisab rüsumunun ilgası, hastanelere bir düzen getirilmesi, Trablusgarb'da bir kaza ile bir kasaba arasında yapılmakta olan imar ve iskân faaliyeti, Trabzon'un maliye ve mülkiye idaresi hakkında yapılacak usul, taşradaki boş arazilerin durumu, gelen gidenlerin nüfus yoklama kayitlarının tutulmas1, vapur ve yelkenlerle bazı yerlere gönderilen kimselere emtia gümrüğü malından verilen meblağ hakkında konu, Canik sancağındaki çiftliklerin reayasıyla sahipleri arasındaki sorunların giderilmesi, Dersaadet'e gelen Haremeyn ahalisine mürur tezkeresi verilmesi, Trabzon'da tımarlıların beratlarını tahrir ettirmeleri, Dersim sancağının teşkilatı hakkında konu, Ankara'nın Ayaş kazasındaki bir vakıftan vergi talebinin tahkiki, başka bir yere bağlanan karyelerin vergi hisseleri hakkında liste, bağlı oldukları sancak ve kazalardan ayrılarak diğerlerine bağlanan köy, kasaba, ada ve aşiretler hakkında konular, Karahisar-1 Şarki sancağına bağlı bir nahiyenin Giresun'a bağlanması, karye teşkili, başka bir yere evlerini taşıyanların vergilerinin o mahallere devredilmesi, taşrada memul edilen fazla hasılatın 
durumu, tahrir-i nüfus ve emlaki biten kazanın vergi ve bedelat-1 askeri miktarı, Tuna vilayeti dâhilindeki yerlerin evkaf işlerinin idaresi hakkındadır. Defter, Subhi Beyefendi'nin Maarif-i Umumiye Nezareti'ne tahvil-i memuriyeti hakkındaki yazıyla son bulmaktadır.

\section{e. Buyruldu ve İlmühaber Defterleri 5}

Buyruldu ve İlmühaber Defterleri fonunun beşincisi olan defterin fihristten önceki iki sayfasının birinde tuğralı ve üzerinde kuruş cinsinden çeşitli meblağları gösteren dairesel semboller (damga), diğer sayfada ise mühürler bulunmaktadır. 41 × $25 \mathrm{~cm}$ ölçülerinde, 1-12 arası ile 98 . sayfaları "m" (mükerrer) olan bu defter, Eylül 1861/Rebiülevvel 1278 ile Nisan 1881/Cemaziyelevvel 1298 tarihleri arasını kapsamakla birlikte son konusu Haziran 1886/Ramazan 1303 tarihini taşımaktadır. Dördüncü sayfada başlayan ve yedinci sayfada son bulan fihrist bölümünden sonraki sayfada köy listesi verilmiştir. Dokuzuncu sayfada hazine-i hümâyun hademelerinden birinin hafidi hakkında, sonraki iki boş sayfanın ardından on ikinci sayfada manastırlara dair basılan bir nizamname hakkında ilmühaberler vardır. İlk on iki sayfadan sonraki on iki sayfa ise "m" (mükerrer) olarak gösterilmiştir. Mükerrer sayfalardan sonra numarası on üçten devam ettirilen defterin son sayfa numarası yüz altmış ikidir (yazılı kısım seksen yedi varak). Defterde yazı tipi rik'adır.

Başlangıç kısmında sayfa numarası, konu ve tarih bilgilerinin verildiği bir fihrist bulunan defterin içeriği genel itibariyle şöyledir:

Defterin fihristten birkaç sayfa sonra gelen ve " $m$ " (mükerrer) olarak gösterilen ilk sayfasında "Bism-i Subhanehu ve Teâla, Haza Defter-i Buyuruld1-i Âli ve İlmühaber Derzaman-1 Sadr-1 Suduru'l-Vüzera Hazreti Mehmed Emin Âli Paşa Yesserallahu Mâ Yurid ve Mâ Yeşa ve Vekâlet-i Nezaret-i Celile-i Hariciye Hazreti Mehmed Cemil Beyefendi Nâle Mâ Yetemennahu El-Vâki Fi Gurre-i Ra Sene 1278" yazılıdır. İlk konunun başlığ1 "Meclis-i Vâlâ mazbatası" ve burada ele alınan konu, muhacirin iskânına memur şahsın tahriratı üzerine düzenlenen mazbata ve irade-i seniyye hakkındadır. Bundan sonraki konular genel itibariyle Yusuf İzzeddin adıyla bir karye teşkili, muhacir iskânları, taşrada tahkik ve muhakeme için tayin edilen memurların hareketleri, Nişan-1 Osmani hakkında nizamname, cülus-1 hümâyun vukuunda beratların yenilenmesi, Sadaret'ten yazılan buyruldulara "sah" çekilmeyip mühür basılması, patrik intihabı hakkında nizamname ve sair yazı, piskopos olacakların intihap usulüne dair nizamname ve sair yazı, metropolit heyetiyle teşkil biçimi, Meclis-i Muhtelit-i Daimi'nin teşkili, İstanbul patriği ile piskopos ve sair mamurların maaşları ve manastırlar hakkında nizamname, Nişan-1 Osmani hakkında 
nizamname, Mekteb-i Maarif'te süresini tamamlamayanların kalemlere alınmamaları, memurların hizmeti terk etmemeleri, gümrük eminlerine yazılacak şeylerin gümrük emanetine yazılması, taşra memurlarının hazineye kefil göstermeden görev merkezlerine gitmemeleri, hulefa ve kâtiplerin görevlerine devam etmeleri, hulefa ve kâtiplerin kâğıt haffaflı̆̆1 etmemeleri, Hayriye ve Avrupa tüccarının arzuhallerini beylikçilik makamına takdim etmeleri, Dersaadet Ermeni patriğinin intihab sureti, kalemlerdeki kırtasiye meselesi, yabanc1 devlet konsolosları, zabitan ile kalem hulefasinın görevlerine devam etmeleri, vezir ve mutasarrıf kapukethüdalarının vazifeleri, tüm ruhbanlar ile bunların mekânlarına gümrük muafiyeti hakkında nizamname ve sair yazı, murabahacılık usulünün tadili, evkaf mal müdürlerinin görevleri, Divan-1 Muhasebat'in teşkil ve tanzimi, ruhbanların gümrük vergisinden muafiyetleri, bir miras davasının tekrar dinlenmesi, Mektubi-i Hariciye hulefasından biriyle bir kadın arasındaki çiftlik meselesi, vilayet usulü ve Tuna vilayetinin teşkili, kumpanyaların ihraç edecekleri senetlerin damgalanması, havale edilen evrakın kalemlerde hızla düzenlenmesi, varaka-i sahihaya yazılmayan hususi evrakın reddi, eyalet ve livalarda miri emvalin tahsili, Tuna vilayetinin bazı vazifeleri, damgasız kâğıtlı istidaların kabul edilmemesi, Pasaport Odası hakkında nizamname, kasaba ve pazar yerlerinde alınıp satılan hayvanlardan fazla vergi alınmaması, davalarla ilgileri olan ülke dışındaki kişilerin ihzar tezkereleri, umumi maaşlardan yapılan indirimler; evkaf mallarının ferağ, intikal ve boş olmaları halinde hazinece yapılacak muamele; rüşdiye mektepleri şakirdlerinin imtihanları ve askeri mekteplere geçişleri, metrukât ile muhallefat ve sair işler için istihdam edilen hademeye belli oranlarda resim tahsis edilmesi, Tuna'da vapur işletecek bir şirketten on sene süreyle patenta resmi istenmemesi, bir şahsın çiftliği merasında ağnam otlatıldığı için zararının tazmin edilmesi, mahrec-i aklamdan şahadetnamesiz çıanların kalemlere kabul edilmemesi, borcu olanlar için mahkeme kararı olmadan taksit fermanı verilmemesi, Ticaret ve sair nizamiye mahkemelerinde görülecek davalardan belli oranlarda harç alınması, iki manastır mütevellileri arasındaki kışlak meselesi, önemli meselelerin zamanında ikamesi ve memurların dairelerine devam etmeleri, izn-i sefinelerin liman idaresi tarafından doldurulması, vakfiyeye dair işlerin hızlı bir şekilde görülmesi, Kudüs'ün Suriye'den irtibatının kesilmesi, Protestanların mabet ve mektep olarak yaptıkları hanenin civardaki yapılara verdiği zararın giderilmesi; evkaf, divan-1 hümâyun ve Defterhane'deki işlerin harç talebiyle ertelenmemesi, bir mütevelli ile bazı köylerin ahalisi arasındaki orman ve arazi meselesi, ölen bir Rum rahibin Atina Bankası'ndaki parasının verilmesi, bazı köyler arasındaki tartışmanın faslı için mübaşir tayin edilmesi, Darphane'de imal edilen yeni damga hakkında konu, Dersaadet ve 
tevabii emlak idaresinin daire-i zabtiyeye nakledilmesi, nüfus miktarına göre bedelat-1 askeriye alınması, çekilecek telgraflardan ücret alınması, Kudüs Rum patrikhanesi hakkında nizamname, Maarif Nezareti'nin izni olmadan asar-1 atika taharri taleplerine müsaade edilmemesi, yeniden imal edilen evrak-1 sahiha kalıpları, Havale Cemiyeti'nin vazifeleri, bazı yerler için tapu senedi verilmesi ve harçlarının ödenmesi, Alaman neslinden ve Yahudilerden bazı hanelere âşar dışında vergi muafiyeti getirilmesi, Hakikat Gazetesi'ne münasip olan hususların İdare-i Ceride-i Askeriye aracıllğıyla derç edilmesi, mahkemelerden verilip icra cemiyetine ulaşan ilamlar ile memurların borçları için düzenleme yapılması, muamelat-1 tahririye-i dairelerin icrası, senetlere pul yapıştırılması, memurların vaktinde iş başında olmaları, mühimmat yüklü gemilerin Bahr-i Siyah tarafina geçirilmemesi, mezhep işlerinin Adliye Nezareti'ne tahvili, Protestanların işleri için taşrada Protestan vekili adıyla bir memur tayini, mühim ve acil resmi işlerin ertelenmemesi, ölen bir Kudüs rahibinin mirası, Şefkat nişanı hakkında nizamname ve sair yazı, İmtiyaz nişanı hakkında düzenlemeler, müstakil vilayet mahkemelerinin görecekleri davalar, Cezayir-i Bahr-i Sefid vilayetinin 1slahatı, kaide-i müteselsileye riayetle memur seçilmesi, resmi dairelerle şahıslar arasındaki davalar hakkında konu, Bahr-i Siyah Boğazı'ndan geçecek gemilerden alınacak müruriye, hahamhane hakkında nizamname ve sair yazı, arazi davalarına dair yazıların birbirlerine mübayeneti, merhum Kamil Paşa'dan kalan nişanların bedelinin varislerine verilmesi, tekaüd sandığı sermayesi, İslam'ı kabul eden kimseler hakkında konu, İslam'ı kabul eden Ermeniler hakkında tezkere, Hariciye dairesi tahsisatından kesinti yapılması, zabtiye mensupları terfi edince rütbelerine dair emr-i âlilerin yenilenmesi, mümtaz eyalet ve emaretlerin merkezi idareleri, divan-1 hümâyun kalemleri hulefasından ölen bazılarının yakınlarına verilen maaşların kesilmesi, İstanbul Rum Patrikliği ruhani hükümeti altındaki manastırlarla ilgili nizamname ve sair yazı, Ermeni patrikhanesi tarafından ruhsatsız olarak iane biletleri satılmasının önlenmesi, çekirgenin toplanıp telef edilmesi, Tur-1 Sina piskoposluğuna getirilen şahıs ile ilgilidir.

\section{f. Buyruldu ve İlmühaber Defterleri 6}

Buyruldu ve İlmühaber Defterleri fonunun altıncısı olan defterin kapak kısmında kısmen silik olarak "Buyuruldı..., Min Evâil-i Cumadelâhire Sene 1(2)98" yazılıdır. 25 x $35 \mathrm{~cm}$ ölçülerinde, bir sayfası boş olan bu defter, May1s 1881/Cemaziyelâhir 1298 ile Haziran 1895/Zilhicce 1312 tarihleri arasını kapsamaktadır. İki yüz on yedinci sayfada son bulan bu defterin yazılı kısmı yüz yirmi iki varaktır. Defterde kendilerine hitap edilen kesimler ve kurumlar genel itibariyle; Maliye, Hariciye ve Adliye nezaretleri, Divan-1 
Hümâyun Beylikçiliği (Beylikçi-i Divan-1 Hümâyun), Sadaret, Dâhiliye Nezareti, Sicill-i Nüfus İdare-i Umumiyesi, Divan-1 Hümâyun Kalemi'dir.

Başlangıç kısmında sayfa numarası, konu ve tarih bilgilerinin verildiği bir fihristi bulunan defterde fihrist, yirmi üçüncü sayfaya kadar "bn" (başta numarasız) işareti ile birlikte devam etmektedir. Fihristten sonra "bn" yirmi yedi sayısına kadar süren sayfalarda bir binbaşının verdiği pusula, çeşitli mühürler, Diyarbakır'daki Süryanilerle ilgili bilgi, Üsküdar Bağlarbaşı'ndaki bir caminin hasilatı meselesi vardır. Defterin ilk kısmında "bn" olarak gösterilen sayfalardan sonra birden başlayan ilk sayfanın başlığı "Haza Defter-i Buyuruldı Derzaman-1 Başvekil Hazreti Said Paşa ve Nezaret-i Celile-i Hariciye Hazreti Asım Paşa Nâle Mâ Yetemennahuma El-Vâki Fi Evâil-i Cumadelâhire Sene 1298" yazılıdır." Bundan sonra defterde işlenen konular genel itibariyle Üsküdar ve Bilecik destgâhları asarı olan mamulat, Suriye taraflarına giden ecnebilerin keşif haritası almaları, zeametler, Ermeni kilise inşası, rahiplerin metrukâtı, cami ve çeşme gibi umumi yerlerin inşası, rüşdiye mekteplerinin artırılması ve 1slahı, kâtiplerin maaş zammı, sadakat ve şecaat madalyası nizamnamesi ile yabancılara (ecnebi) verilecek nişanlara dair nizamname, Divan-1 Hümâyun dairesinden yapılan yazışmaların usulleri, telgraf hatlarının uzatılması; bazı nahiye, karye ve çiftliklerin uygun kaza ve sancaklara bağlanmaları; muhtelif yerlerde kaymakamlık, kasaba, nahiye ve karye teşkili; muhacirler için karye ve mahalle teşkili; muhtar ve imam tayinleri; konsolos ve konsolos vekili tayinleri, Avusturya imparatorunun İtalya seyahati, Kudüs'te bazı Musevilerin Alman neslinden olduklarına dair iddiaları, Katoliklerin ölenleri için arazi verilmesi, müdür maaşının karşılanması, yeni teşkil edilen mahalle ve köylere isim verilmesi, çeşitli mahalle ve köylerin isimleri; karyenin nahiyeye tahvili; sancak, kaza ve nahiyelerin kaymakamlığa tahvili; kaymakamlığın müdürlüğe tahvili; liva ve mutasarrıflık teşkili; alt idari birimin veya vilayetin müstakil mutasarrıflığa tahvili, nesebi meçhul kimselere ve İranlılara kadınların nikah akdi yapılmaması, manastırlar tarafından yapılan inşaat, taşrada idari birimlerin bir yerden başka yere nakilleri, konsolosların görevleri dışındaki muamelelerine izin verilmemesi, İranlıların işlerinin görülmesi, Almanlı tabir olunan taife, Katolik mezhebine geçen Ermeniler için muhtar seçilmesi, muhacirler için muhtar seçilmesi, İngiltere'nin Suriye dâhilinde harap olan mektep binalarının yerine yenilerini inşa etmesi hakkında muhabere, çeşitli kesimler arasındaki düşmanlığa son verilmesi, Dersaadet limanından çıkan gemiler için ferman verilmesi, tarlaların âşar bedellerinin takdir edilmesi, Londra'daki bir etibba cemiyetinin Şam'da hastane inşa etmesi, kazada hükümet konağı inşası, karyelerin miktarı ve nüfusu, Katoliklerin mabetlerine çan asılması, mabetlerdeki çanların tamir edilmesi, Suriye'deki 
Rum taifesinin muamelesinin ifası, Ermeni patriklik makamında takrirle talep olmadığı sürece inşaat ve tamire izin verilmemesi, Eytamhane inşası hakkında konu; cami, medrese, çeşme ve sair inşa ettiren şahsa nişan verilmesi, Ermeni Katolik mektebi hakkında konu, muhacirlerin iskanı, ordu merkezleri için muayene-i intihaiye ile numara keşidesi muamelesinin yapılması, yıkılan Bulgar kilisesinin yerine yenisinin inşası, Bulgar ahali için kabristan ittihazı, babasından kalan iftihar nişanını kullanmak isteyen kişinin durumu, Rus ordularının ölen askerlerinin kemiklerinin defni, Konya'da Amerikan mektebi tesisi, Selanik dâhilinde Dersaadet Bankası uhdesindeki madenin durumu, Rum metropolit ve piskoposlarına mahsus yerin yenilenmesi, Divan-1 Hümâyun kalemine muallim ve efendi alınması, Rum milletine mahsus kabristan hakkında konu, padişahın iradesi olmadan mektep inşasına izin verilmemesi ile ilgilidir.

\section{g. Buyruldu ve İlmühaber Defterleri 7}

Buyruldu ve İlmühaber Defterleri fonunun yedinci olan defterin kapak kısmında "İlmühaber Defteri Min 1289 İlâ" yazılıdır. 29 x $20 \mathrm{~cm}$ ölçülerinde, başta üç sayfa boş numarasız, 4-70 ile 175-297 arası sayfaları boş olan bu defter, Kasım 1865/Receb 1282 ile Mart 1891/Receb 1308 tarihleri arasını kapsamaktadır. Yüz yetmiş dördüncü sayfada son bulan bu defterin yazılı kısmı elli dört varaktır.

Fihristi olmayan defterin 1-3 arası sayfalarını kapsayan ilk kısmında, defterin birinci sayfasında istifli bir hat yazısıyla "Kalem Zeamilerinin Maaşa Tahviliyle Bazı Name-i Hümâyun Kozarı ve İktiza Eden Kırtasiye ve Sair Levazımat-1 Kalemiye İçün Hazine-i Hassa ve Maliye Taraflarına Yazılan Buyuruldı-i Âli Defteridir Fi Evâil-i Receb Sene 1282” yazılıdır. Bu yazıdan sonraki ilk konu Maliye Nezareti'ne hitapla başlamaktadır ve Paris'te akdedilen umumi telgraf anlaşmasının tasdiknamesi için gereken kabın imal edilmesi hakkındadır. Sonraki konular genel olarak önemli belgeler için mahfaza, kap, koza ve sairin Darphane-i Âmire'de imal edilmesi ile ilgilidir. Dördüncü sayfayla birlikte gelen boş sayfaların ardından yetmiş birinci sayfadaki başlıkta "Haza Defter-i İlmühaber, Derzaman-1 Sadr-1 Suduru'1-Vüzera Hazreti Ahmed Midhat Paşa ve Nezareti Hariciye Hazreti Mehmed Cemil Paşa Nâle Mâ Yetemennahu El-Vaki Cumadelâhire Sene 1289" yazılıdır. Başlıktan sonraki konular genel olarak bazı sancakların ve köylerin bağlandıkları yerler, Ankara ve Kayseri'de göllerde meydana gelen çorak tuzların muhafazası, kaymakamlık merkezinin yer değiştirmesi, nahiyenin başka bir kazaya ve kazanın başka sancağa bağlanması, karyelerin başka kazaya bağlanmaları; vilayet, sancak, kaza ve nahiye teşkili; müdürlüğün kaymakamlık yapılması, sancakların vilayet haline getirilmesi, İngiltere ve Almanya tebaasından olan kişilerin maden 
imtiyazı için başvuruları, muhacirlerin ziraat için arazi kullanmaları, Ankara civarındaki köylerin isimleri ve Ankara'ya olan mesafelerini gösteren cetvel, vergiden muaf olma talepleri, muhacirlerin yolsuz hareketleri, kaymakamların azil ve tayin sürecinde alacakları maaşlar, zeamet sahibi olup çocuksuz ölen kişilerden kalan zeamet bedelinin zaptı, müstakil livalar ile bir vilayete bağlı liva, kaza ve kasabaların sene sonuna kadar gelir giderlerini gösteren cetvellerinin düzenlenmesi, nühas madeni hasılatından hazineye vergi verilmesi, nehir mecralarının 1slahı ve köprülerin tamiri, miras işlerinin yürütülmesi, defter harici tımarların kayıt altına alınmaları, metruk tımarlılardan zaptiyeye dönen ve bunlardan mütekaid ve hay olanların bedelleri hakkında nizamnameler; rapt ve ilhak maddesinin muamelesi, Lazistan sancağının idaresi hakkında görüşler, Divan-1 Hümâyun kalemine mahsus zeametlerin bedelleri, beş yüz kuruş ve üzeri maaş alan memurların maaşlarından Evkaf hazinesine pay ayrılması, bir kazadan diğerine ilhak edilen karyelerin isimleri; âşarı ve nüfusu başka kazalara vergisi ise başka kazaya ait olan karyelerin isimleri, Mekke emaretiyle sair kişilere gönderilecek name-i hümâyunlar için altın yaldızlı koza imal edilmesi hakkındadır.

\section{h. Buyruldu ve İlmühaber Defterleri 8}

Buyruldu ve İlmühaber Defterleri fonunun sekizinci ve sonuncusu olan defterin kapak kısmında "Buyruldı" yazılıdır. 29 x $41 \mathrm{~cm}$ ölçülerinde, başta üç numarasız boş, 1-2 ile 37-274 arası sayfaları ve son sayfası boş olan bu defter, 1913/1331 ile 1918/1336 y1lları arasını kapsamaktadır. Otuz altınc1 sayfada son bulan bu defterin yazılı kısmı on yedi varaktır.

Fihristi olmayan defter genel itibariyle mektep muallimlerinin efrad-1 müeccele meyanına dâhil edilmeleri, Amerikan mektebi yetersiz olduğundan başka bir yere nakledilerek yeniden inşa edilmesi, Divan-1 Hümâyun daireleri ve burada görevli memurlar hakkında düzenleme, Beyoğlu'ndaki bazı hane ve arsaların durumu hakkında tahkikat ve muhakeme, veraset davalarında gayrimüslim miras erbabı hakkında patrikhaneden bilgi alınması, Rum cemaatine mahsus bir mektep inşası, bir kazada inşa edilerek fakirlerin ücretsiz tedavisine tahsis edilen hastanenin vergisi, Kadıköy'de bir Ermeni cemaati mektebinin vergiden muaf olması, Rumlara mahsus kilise inşası, bir Latin kilisesi hakkında görüşler, bazı kazalarda inşa edilen kiliseler, Diyarbakır'daki Süryaniler ile Ermeniler arasında sorun olan manastır hakkında tahkikat, devlet hizmetindeki yabancı zabitlerin rütbe terfii hakkında Harbiye Nezareti'ne hitap eden yazı, Mardin'de Amerika tebaasından birinin hastanesi hakkında konu, Fransa ile Osmanlı Devleti arasında kararlaştııılan itilafname hakkında konu, ferman ve beratlara yazılacak hitabın şekli hakkında Divan-1 Hümâyun beylikçiliğine yazı, 
Mardin'deki gayrimüslim din adamlarıyla kiliselerin durumu hakkında konu, Urfa'daki Amerikan mektepleri hakkında konu, hanedan-1 saltanat mensuplarının müsekkafatının vergiden muaf tutulması ile hanedan mensupları hakkındaki sair hususlar, bir kazada cami ve medrese yakınında inşa edilen bir kilise hakkında konu, İngiliz bir mektebe dersane ilavesine ruhsat verilmesi hakkında müzakereler, bilâ bedel nişan ve madalya verilmemesi, Divan-1 Hümâyun dairesine alınacak kâtiplerin vasıfları hakkında bilgileri içermektedir.

\section{Sonuç:}

Osmanlı Devleti'nin iç ve diş bürokratik işlemlerinin ve yazışmaların yürütüldüğü, tüm nezaretlerin ve meclislerin bağlı bulunduğu hükümet merkezi durumundaki Sadaret makamı, özellikle 19. Yüzyılda saray dışında etkin bir konuma sahipti. Burada tutulan kayitlar ile merkezle ve taşrayla yürütülen yazışmalar, birçok farklı belge ve defter halinde günümüze kadar varlığını devam ettirdi. Tanzimat öncesinde Bab-1 Asafi, Tanzimat döneminde ve sonrasında ise Sadaret olarak "A" harfi şeklinde tasnif edilen bu evrak grubu, Osmanlı tarihini araştıranlara önemli veriler sunarken, özellikle devlet merkezi olan İstanbul ve bunun yanı sıra taşradaki idari yapı hakkında da çok kıymetli bilgileri ortaya koydu.

$\mathrm{Bu}$ makalede ele alınan Buyruldu ve İlmühaber Defterleri, Sadaret makamından çıkan emirleri ihtiva eden önemli bir fon durumundadır. Dönem itibariyle 1811-1918 y1lları arasını kapsayan defterlerin her biri, ele aldıkları konular itibariyle bazı hususiyetleri kendi içlerinde barındırmaktadırlar. Defterlerin bazılarında, araştırmacıların işini çok kolaylaştıracak bir etkene sahip olan fihristler bulunmaktadır. Fonun bir, iki, dört, yedi ve sekiz numaralı defterlerinde fihrist yok iken üç, beş ve altı numaralı defterlerinde ise fihrist bulunmaktadır. Konu yelpazesi itibariyle daha ziyade birinci defterde İstanbul ve yakın çevresiyle ilgili konular, ikinci defterde Müslümanların yaşam tarzları ve çocuk düşürmenin önlenmesi gibi sosyal meseleler, üçüncü defterde yabancı devletlerle olan münasebet ile gayrimüslimlerin işleri hakkında bilgiler bulunmakta; bunun dışında üç defterde ticari meseleler, gemilerin geçiş izinleri, seyahatin kontrolü ve gümrük vergileri hakkında konular ele alınmaktadır. Dördüncü defter ile akabinde gelen diğer Buyruldu ve İlmühaber defterlerinde artık Osmanlı taşra idari yapısı da işlenmektedir. Bu bağlamda memur tayinleri ve azilleri ile mahalli birimlerin teşkili hakkında verilen bilgiler, şehir tarihi çalışacak kişiler için büyük önem arz etmektedir. Defter fonunun ikinci kısmında bulunan yedinci ve sekizinci defterde bulunan bilgilerden hareketle de mahalli düzeyde önemli sosyal ve idari sonuçlara ulaşmak mümkündür. 
Hülasa bu makalede incelenen defterler, Osmanlı'nın hükümet merkezi durumundaki bir makamdan ilgili mercilere gönderilen yazıları içermesi ve hadiseler hakkında resmi bilgileri sunması açısından son derecede önemli olan birinci el kaynaklardır. Söz konusu defterlerde döneme ait siyasi, iktisadi, idari ve sosyal alanlarda çok kıymetli bilgiler elde edilmektedir. Bu bilgilerin işlenmesi yoluyla da tarih literatürüne büyük katkılar sağlanacaktır. 


\section{KAYNAKÇA}

\section{A- Arşiv Kaynakları}

BOA, A.DVS.BUY.İLM.d., (Başbakanlık Osmanlı Arşivi, Babı Asafi Divan-1 Hümâyun Sicilleri Buyruldu ve İlmühaber Defterleri), numara: 1, 2, 3, 4, 5, 6, 7, 8.

\section{B- Kitap ve Makale}

Başbakanlık Osmanlı Arşivi Rehberi, Hazırlayanlar Yusuf İhsan Genç ve diğerleri, Başbakanlık Basımevi, Ankara 2010.

Akyıldız, Ali, Tanzimat Dönemi Osmanlı Merkez Teşkilâtında Reform (1836-1856), Eren Yayıncılık ve Kitapçılık, İstanbul 1993.

Doğan, Muzaffer, “Divân-1 Hümâyûn'dan Babıâli’ye Geçiş”, Yeni Türkiye, cilt 31, Ankara Ocak-Şubat 2000.

Gökbilgin, M. Tayyib, Osmanlı Imparatorluğu Medeniyet Tarihi Çerçevesinde Osmanlı Paleografya ve Diplomatik İlmi, Edebiyat Fakültesi Basımevi, İstanbul 1979.

İpşirli, Mehmet, "Sadrazam”, Türkiye Diyanet Vakfi İslam Ansiklopedisi, cilt 35, İstanbul 2008.

Kütükoğlu, Mübahat S., "Buyruldu", Türkiye Diyanet Vakfı İslam Ansiklopedisi, cilt 6, İstanbul 1992. 2000.

,İlmühaber", Türkiye Diyanet Vakfi İslam Ansiklopedisi, cilt 22, İstanbul, Osmanll Belgelerinin Dili (Diplomatik), Kubbealtı Neşriyatı, İstanbul 1994.

Mumcu, Ahmet, Divan-ı Hümayun, Phoenix Yayınevi, Ankara 2007.

Serin, Muhittin, "Rik'a", Türkiye Diyanet Vakfi İslam Ansiklopedisi, cilt 35, İstanbul 2008.

Şemseddin Sami, Kâmûs-ı Türki, cilt 1-2, Çağrı Yayınları, İstanbul 2001.

Uzunçarşıll, İsmail Hakkı, Osmanlı Devletinin Merkez ve Bahriye Teşkilatı, Türk Tarih Kurumu Basımevi, Ankara 1988. 
Ekler:

Buyruldu ve İlmühaber Defterleri'den farklı yazı örnekleri:

EK-1: BOA, A.DVS.BUY.ILLM.d., numara 1, sayfa 10.

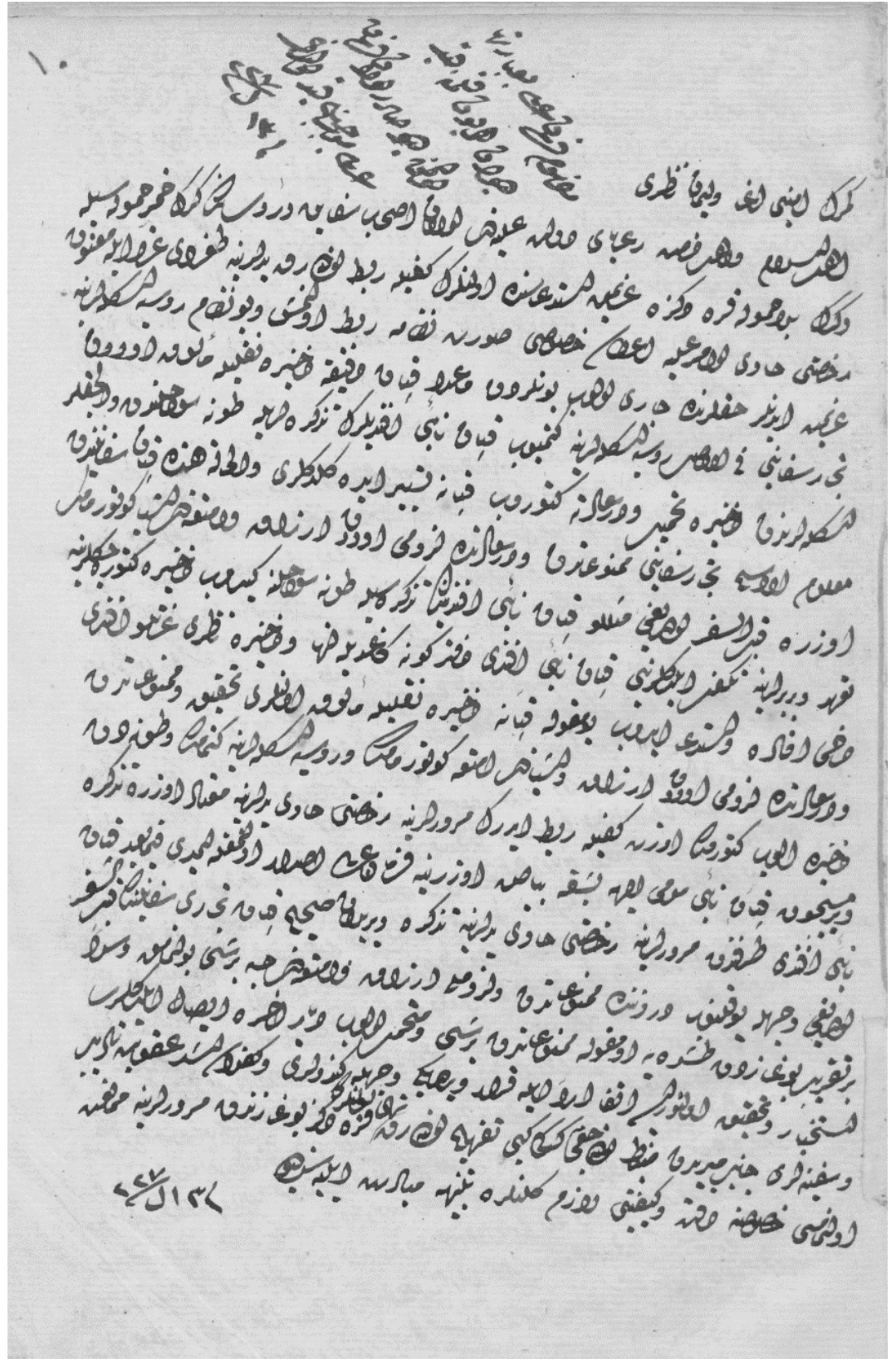


EK-2: BOA, A.DVS.BUY.İLM.d., numara 6, sayfa 14.

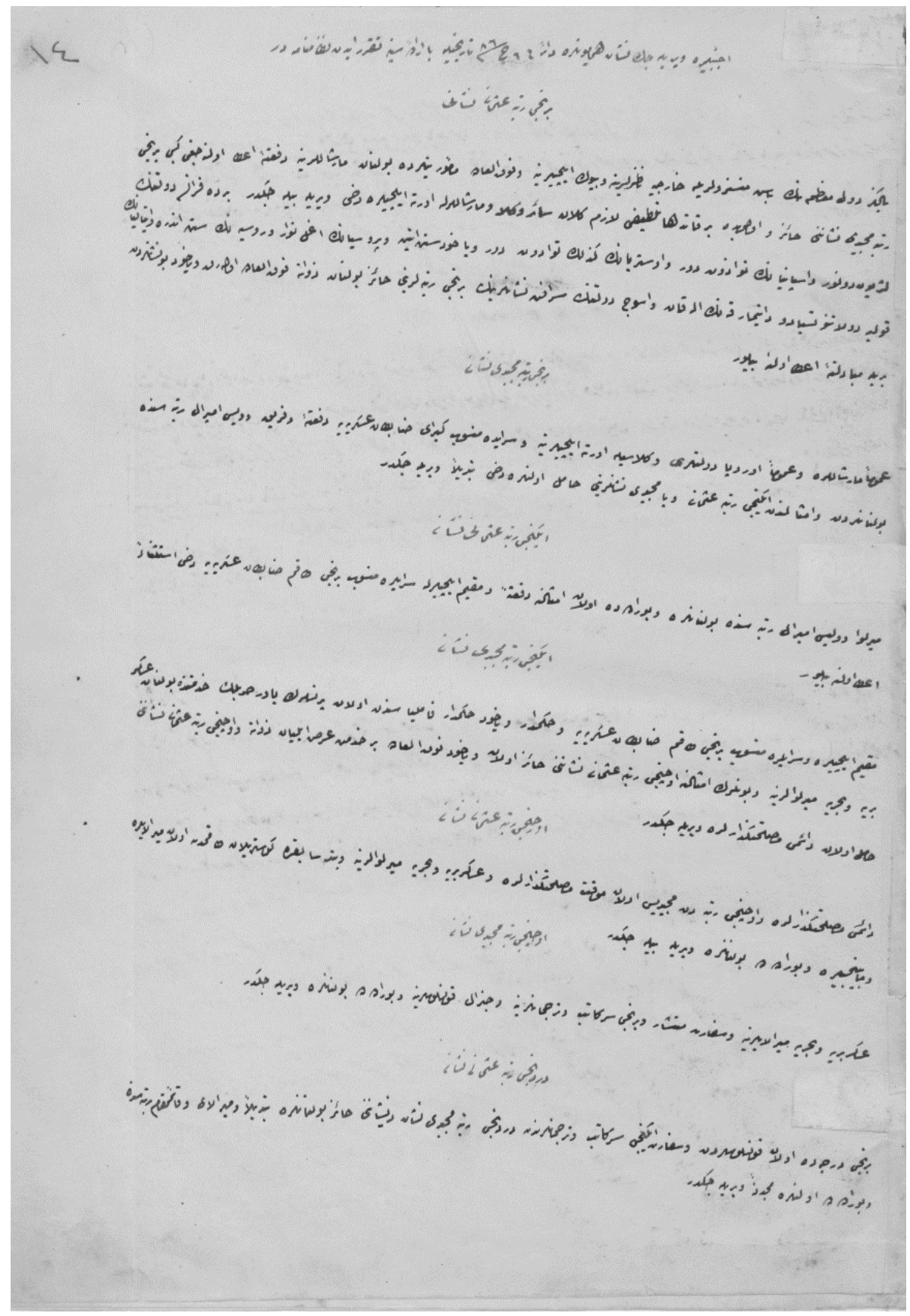


EK-3: BOA, A.DVS.BUY.İLM.d., numara 8, sayfa 35.

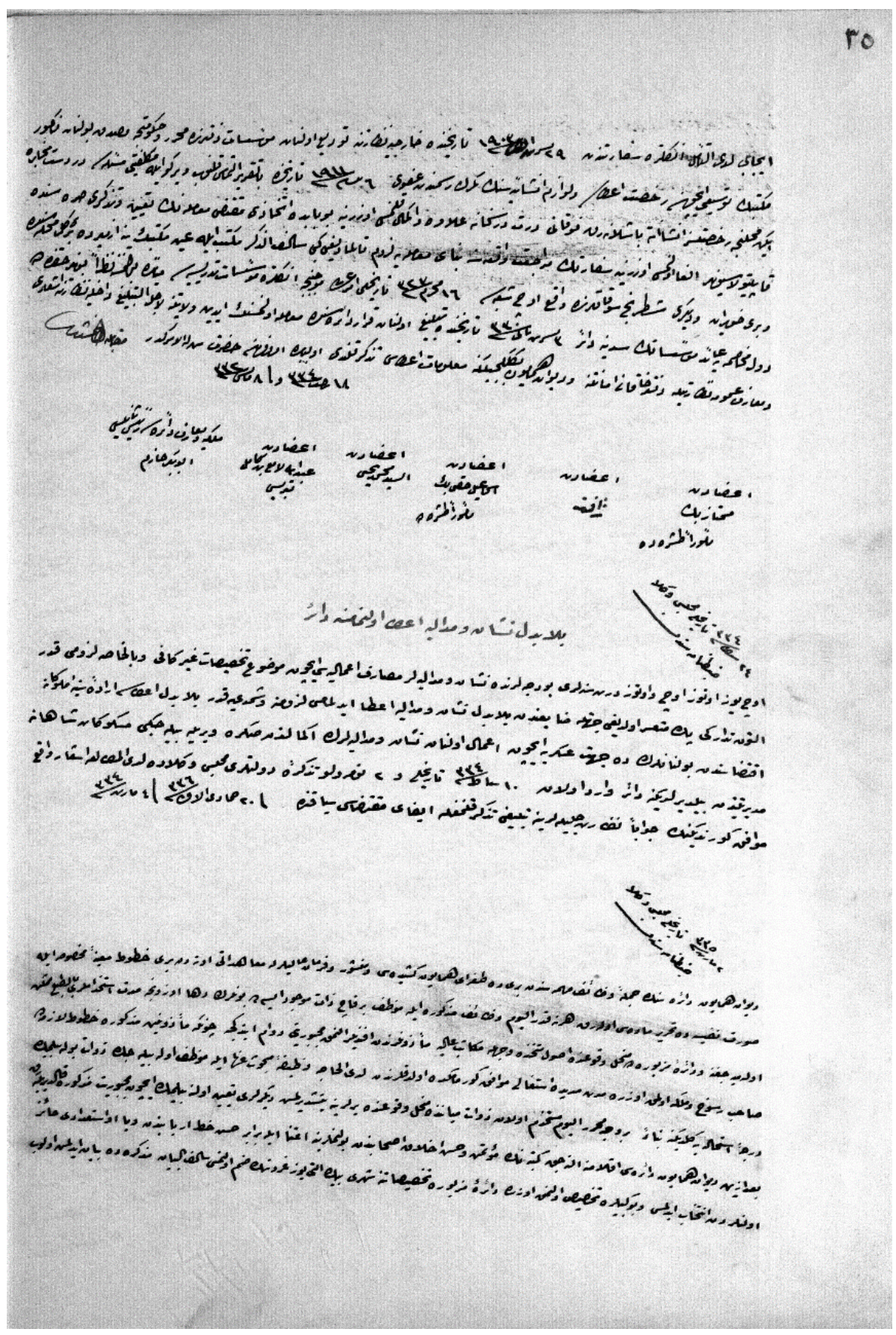

